\title{
The effect of l-tryptophan on the sleep-dream cycle in man'
}

ERNEST L. HARTMANM, M. D. TUFTS UNIVERSITY SCHOOL OF MEDICINE

The effect of l-tryptophan (120 mg/ $\mathrm{kg}$ at bedtime) on sleep was investigated on eight normal human $S$ s over 91 recorded laboratory nights. Subjectively, tryptophan was seen as a sleeping medication. Total sleep was not significantly increased. Total D-time was significantly increased, as was D-time percent for the second half of the night but not for the nights as a whole.

The nightly sleep pattern of a young human adult is now well known; it includes a total D-time (REM-time) of about $100 \mathrm{~min}$ or $\mathbf{2 0 - 2 5 \%}$ of total sleep (Aserinsky \& Kleitman, 1953; Dement \& Kleitman, 1957b). This amount is remarkably constant under most conditions but can be altered by drugs. The vast majority of drugs studied, including barbituates, other hypnotics, phenothiazines, analeptics, and antidepressives all reduce Dtime and D-time percent in man (Hartman, 1967a). Reduced $\mathrm{D}$-time appears to be a nonspecific indication of disturbed or altered sleep. Therefore any agents capable of increasing D-time would be of theoretical interest.

Only reserpine (Hartmann, 1966) and to some extent LSD (Muzio et al, 1966) have been shown to produce an increased D-time in man. This had led to interest in brain amines, especially serotonin and norepinephrine. We have recently shown that altering brain serotonin levels appears to alter the sleep-dream cycle length in the rat (Hartmann, 1967).

The effects of 1-tryptophan are studied here. Serotonin itself does not pass the blood-brain barrier to any appreciable extent, but tryptophan does so easily and a portion of it is then converted to 5-OH-tryptophan and serotonin. Tryptophan feeding clearly increases brain serotonin levels in animals (Hess et al, 1959); it is not possible to demonstrate this directly in man, but the doses of tryptophan used here (6-10 g) have been shown to have definite behavioral effects which could be attributed to the central changes in serotonin levels (Smith \& Prockop, 1962); however, the effect of other products of tryptophan metabolism, especially tryptamine, cannot be ruled out. Our hypothesis was that D-time would be increased and the sleep-dream cycle length decreased by 1-tryptophan.

One other study of the effects of 1-tryptophan on sleep (Oswald et al, 1966) reported that the time from sleep onset to the first D-period was greatly reduced by 1tryptophan (7.5 g) in a few Ss; however, all-night sleep records were not obtained.

Method

Eight normal human volunteers, 18-31 years old, slept in the laboratory once a week for at least 10 weeks each.
All-night EEG and eye movement records were obtained by the usual techniques (Dement \& Kleitman, 1957a). Bedtime and day of the week were kept constant throughout the series for each S. Each was allowed $8 \mathrm{~h}$ in bed on each study night. The first two nights for each $S$ were considered adaptation nights, and are not included in the results. At least four further nights without medication and at least one placebo night later in the study were obtained to establish a baseline for each S. On three or more nights for each $\mathrm{S}$, at weekly intervals, 6 to $10 \mathrm{~g}$ of 1-tryptophan $(120 \mathrm{mg} / \mathrm{kg})$ was administered $30 \mathrm{~min}$ before the $\mathrm{S}$ was put to bed. The tryptophan was mixed into $8 \mathrm{oz}$ of applesauce, forming a palatable although not very tasty concoction. ${ }^{2}$ We had established that higher doses of tryptophan produced side effects-dryness of the eyes and palpatations-which kept the Sfrom getting to sleep. Records were scored blind for waking, Ssleep, and $\mathbf{D}$, and the variables listed in Table 1 were then calculated.

Results

Table 1 first presents the results for each of the eight Ss as mean values for control nights and for tryptophan nights. Overall means are presented at the bottom of the table.

No very large changes were produced by the administration of tryptophan. Total sleep time was slightly increased, and it is interesting that most Ss reported that they thought they were getting a "sleeping pill." On two occasions Ss began to fall asleep 15-20 min after eating the tryptophan, while electrodes were still being attached.

Total D-time was significantly increased, though the overall mean value on 1-tryptophan was only $8 \%$ higher than the mean control value $(p<.05$, for the group as a whole by the Walsh Test for related Samples, Siegel, 1956). In two Ss, No. 1 and No.5, the difference was significant within that $S(p<.05)$ comparing all control nights and all tryptophan nights by the Mann-Whitney Utest. D-time as a percent of total sleep was not significantly increased. However, in a separate analysis, each night of sleep was split into two equal halves. L-tryptophan nights and control nights were not significantly different for the first half of the night, but both $D$-time and D-time percent were significantly higher after 1tryptophan for the second half of the night.

Time from sleep onset to the first D-period was not significantly changed. The number of awakenings, and number of D-periods were not effected by tryptophan. The mean sleep-dream cycle length was shorter on tryptophan nights, but this did not reach statistical significance. 
Table 1. The Effect of L-Tryptophan on Human Sleep. Summary of 91 all-night $(8 \mathrm{~h}$ ) sleep recordings in 8 human Ss.

\begin{tabular}{|c|c|c|c|c|c|c|c|c|}
\hline & & & & $\mathrm{Mec}$ & Values & & & \\
\hline Subject & & $\begin{array}{l}\text { Total Sleep } \\
\quad(\text { Min })\end{array}$ & $\begin{array}{l}\text { Total D-time } \\
\quad(M i n)\end{array}$ & $\begin{array}{c}\text { D-time } \\
\text { percent } \\
(\text { Min })\end{array}$ & $\begin{array}{l}\text { Time to first } \\
\text { D-period } \\
\text { (Min) }\end{array}$ & $\begin{array}{l}\text { No. of } \\
\text { D-periods }\end{array}$ & $\begin{array}{c}\text { No. of } \\
\text { Awakenings }\end{array}$ & $\begin{array}{l}\text { Cycle } \\
\text { Length } \\
\text { (Min) }\end{array}$ \\
\hline $\begin{array}{l}\text { 3. Control } \\
\text { Tryptophan }\end{array}$ & $\begin{array}{l}(N=5) \\
(N=8)\end{array}$ & $\begin{array}{l}406 \\
427\end{array}$ & $\begin{array}{c}88.2 \\
103.9 *\end{array}$ & $\begin{array}{l}21.8 \\
24.2\end{array}$ & $\begin{array}{r}87.4 \\
124.5\end{array}$ & $\begin{array}{l}4.5 \\
4.3\end{array}$ & $\begin{array}{l}2.2 \\
2.8\end{array}$ & $\begin{array}{l}83.0 \\
82.3\end{array}$ \\
\hline $\begin{array}{l}\text { 2. Control } \\
T\end{array}$ & $\begin{array}{l}(N=5) \\
(N=4)\end{array}$ & $\begin{array}{l}438 \\
444\end{array}$ & $\begin{array}{r}99.0 \\
109.2\end{array}$ & $\begin{array}{l}22.5 \\
24.6\end{array}$ & $\begin{array}{l}103.0 \\
137.9\end{array}$ & $\begin{array}{l}3.9 \\
3.0\end{array}$ & $\begin{array}{l}5.2 \\
1.8\end{array}$ & $\begin{array}{l}105.1 \\
122.5\end{array}$ \\
\hline 3. Control & $\begin{array}{l}(\mathrm{N}=4) \\
(\mathrm{N}=4)\end{array}$ & $\begin{array}{l}466 \\
463\end{array}$ & 110.0 & 23.5 & $\begin{array}{l}108.0 \\
128.8\end{array}$ & $\begin{array}{l}4.5 \\
40\end{array}$ & $\begin{array}{l}1.2 \\
1.5\end{array}$ & $\begin{array}{l}94.6 \\
97.6\end{array}$ \\
\hline 4. Control & $(N=5)$ & 446 & 88.0 & 19.9 & 130.0 & 4.1 & 2.5 & 90.0 \\
\hline$T$ & $(N=5)$ & 466 & 82.7 & 18.0 & 180.5 & 3.9 & 1.4 & 86.6 \\
\hline 5. Control & $(N=4)$ & 440 & 106.1 & 24.1 & 90.6 & 5.0 & 5.8 & 81.8 \\
\hline $\mathrm{T}$ & $(\mathrm{N}=4)$ & 453 & $126.5^{*}$ & 27.7 & 93.0 & 4.5 & 5.5 & 93.1 \\
\hline 6. Control & $(N=14)$ & 417 & 113.0 & 26.8 & 70.0 & 4.1 & 4.2 & 101.0 \\
\hline$T$ & $(N=4)$ & 443 & 115.5 & 26.1 & 65.8 & 5.0 & 1.8 & 86.4 \\
\hline 7. Control & $(N=9)$ & 433 & 96.0 & 22.2 & 79.7 & 4.5 & 3.4 & 91.6 \\
\hline$T$ & $(N=3)$ & 429 & 83.0 & 19.1 & 65.2 & 5.0 & 4.0 & 90.4 \\
\hline 8. Control & $(N=9)$ & 407 & 81.9 & 20.1 & 97.8 & 3.6 & 4.2 & 101.8 \\
\hline $\mathrm{T}$ & $(N=4)$ & 399 & 92.8 & 23.2 & 97.0 & 3.9 & 4.2 & 85.7 \\
\hline & & & & & rall Means & & & \\
\hline Control Nights & $(\mathrm{N}=55)$ & 431.6 & 97.8 & 22.6 & 95.8 & 4.3 & 3.6 & 95.7 \\
\hline Tryptophan Nights & $(N=36)$ & 440.6 & $104.2^{*}$ & 23.6 & 111.6 & 4.2 & 2.9 & 92.0 \\
\hline
\end{tabular}

* different from control, $p<.05$.

Note: $T=$ Tryptophan. "Time to the first D-period" refers to the number of minutes of sleep (S) occurring before the first D-period. "Cycle length" refers to the number of minutes from the end of one D-period to the end of the next; however, any such "cycle" including over 5 min of waking record is discarded.

In summary, only small changes in sleep and dream patterning occurred after l-tryptophan administration, but these were in the predicted direction-D-time was increased and the cycle length slightly decreased. The dosage was high enough to produce noticeable subjective effects in most Ss: chiefly sleepiness or dizziness, which can probably be attributed to central effects. Even a small increase in D-time may be of interest since almost all centrally-acting pharmacological agents reduce D-time in man. Although other mechanisms are conceivable, the effects found are most likely attributable to central actions of serotonin. These results lend some additional support to the possible involvement of serotonin in the mechanisms controlling the sleep-dream cycle.

\section{References}

Aserinsky, E., \& Kleitman, N. Regularly occurring periods of eye motility and concomitant phenomena during sleep. Science, 1953, 118, 273-274.

Dement, W., \& Kleitman, N. Cyclic variations in EEG during sleep and their relation to eye movements, body motility, and dreaming. EEG Clin. Neurophysiol., 1957a, 9, 673-690.

Dement, W., \& Kleitman, $\mathbf{N}$. The relation of eye movements during sleep to dream activity: an objective method for the study of dreaming. J. exp. Psychol., 1957b, 53, 339-346.
Hartmann, E. Reserpine: Its effect on the sleep-dream cycle in man. Psychopharmacologia, 1966, 9, 242-247.

Hartmann, E. The biology of dreaming. Springfield: Charles C. Thomas, Inc., 1967a.

Hartmann, E. The sleep-dream cycle and brain serotonin. Psychon. $S c i, 1967 \mathrm{~b}$, in press.

Hess, S., Reafield, B., \& Udenfriend, $\mathbf{S}$. The effects of monoamine oxidase inhibitors and tryptophane on the tryptamine content of animal tissues and urine. J. Pharmacol. exp. Ther., 1959, 127. 178.

Muzio, J., Roffwarg, H., \& Kaufman, E. Alterations in young adult human sleep EEG configuration resulting from d-LSD-25. EEG Clin. Ne urophy siol., 1966, 21, 313-324.

Oswald, I., Ashcroft, G., Berger, R., Eccleston, D., \& Evon, J. Some experiments in the chemistry of normal sleep. Brit. $J$. 1966, 112, 391-399.

Siegel, S. Non-parametric statistics for the behavioral science. New York: McGraw-Hill, 1956.

Smith, B., \& Prockop, D. J. Central-nervous-system effects of ingestion of L-tryptophane by normal Ss. New Eng. J. Med., 1962, 267, 1338-1341.

\section{Notes}

1. Supported by grants $M H-08715$ and K3-MH-8522 from the U. S. Public Health Service.

2. An applesauce-placebo was not routinely employed in this study, but two of these Ss later had a night of sleep recorded after $8 \mathrm{oz}$ of applesauce; the recordings for these nights were entirely normal. 